\title{
ANALISIS KUAT TEKAN TERHADAP WAKTU STAND-UP C1-G PERTAMBANGAN BAWAH TANAH PT. NAL SAWAHLUNTO SUMATERA BARAT
}

\author{
Murad MS ${ }^{1}$, Indah Sulistia Ningsih ${ }^{2}$ \\ ${ }^{1}$ Universitas Negeri Padang \\ ${ }^{2}$ Sekolah Tinggi Teknologi Industri Padang \\ Email: muradms@ft.unp.ac.id
}

\begin{abstract}
Abstrak: Daerah penelitian (PT NAL) terletak di Desa Salak, Kecamatan Talawi, Kota Sawahlunto. Tujuan penelitian ini adalah untuk menganalisis kuat tekan batuan dan waktu stand-up yang diperlukan dalam perencanaan penggalian dan pemasangan dukungan penambangan bawah tanah di PT. NAL. Pengumpulan data dalam penelitian ini menggunakan observasi lapangan dan pengujian laboratorium. Metode pemecahan masalah dalam penelitian ini didasarkan pada klasifikasi massa batuan dari Bienalwski (1973) Sistem Nilai Massal Batu atau RMR yang terdiri dari kekuatan tekan UCS, jarak diskontinuitas, Rock Quality Designation (RQD), kondisi solid, kondisi air tanah dan orientasi pemegatan. Hasil analisis kekuatan uji kuat tekan batuan utuh, terlihat bahwa batuan terowongan memiliki nilai UCS 8,835 Mpa (lemah) untuk batu pasir, 13.367 Mpa (lemah) untuk batu lanau dan 4,620 Mpa (sangat lemah) untuk batubara. Berdasarkan sifat fisik, diketahui bahwa setiap batuan memiliki nilai porositas yang rendah. Analisis geomekanik memberikan nilai tertimbang Rock Mass Rating (RMR) dengan kualitas massa batuan kelas II (rock baik) untuk tiga jenis massa batuan. Analisis menggunakan grafik waktu stand-up, lamanya batu dapat menahan self-stress tanpa stand-up time untuk batupasir \pm 2500 jam ( 3 bulan 12 hari) dengan bentang $8 \mathrm{~m}$, batu lanau \pm 2000 jam ( 2 bulan 21 hari ) dengan bentang $8 \mathrm{~m}$ dan batu bara \pm 5000 jam ( 6 bulan 27 hari) dengan rentang $6,8 \mathrm{~m}$.
\end{abstract}

Kata kunci: Kekuatan Kompresi, Waktu siaga, RMR

Abstract: The research area (PT NAL) is located in Salak Village, Talawi Sub-district, Sawahlunto City. The purpose of this research is to analyze the rock compressive strength and stand-up time required in the planning of excavation and installation of support in underground mining in PT. NAL. Data collection in this study used field observation and laboratory testing. The method of problem-solving in this research is based on rock mass classification from Bieniawski (1973) Rock Mass Rating System or RMR consisting of compressive strength of UCS, discontinuity distance, Rock Quality Designation (RQD), solid condition, groundwater condition and orientation discontinuity. The result of the analysis of the strength of the compressive strength test of the intact rock, it is seen that the rocks of tunnel have UCS value of 8,835 Mpa (weak) for sandstone, 13,367 Mpa (weak) for siltstone and 4,620 Mpa (very weak) for coal. Based on physical properties, it is known that each rock has a low porosity value. Geomechanical analysis gives weighted value of Rock Mass Rating (RMR) with rock mass quality of class II (good rock) for the three types of rock mass. Analyzes using stand-up time graphs, the duration of rocks can withstand self-stress without stand-up time for sandstones of \pm 2500 hours ( 3 months 12 days) with an $8 \mathrm{~m}$ span, silt \pm 2000 hours ( 2 months 21 days) with an $8 \mathrm{~m}$ span and coal \pm 5000 hours (6 months 27 days) with a span of $6.8 \mathrm{~m}$.

Keywords: Compressive Strength, Stand-up time, RMR 


\section{PENDAHULUAN}

PT. Nusa Alam Lestari (PT. NAL) Sawahlunto merupakan salah satu perusahaan tambang batubara yang menggunakan sistem tambang bawah tanah dalam kegiatan produksinya, adapun metode penggalian yang digunakan yaitu metode room and pillar. Penambangan bawah tanah sangat identik dengan resiko subsidence yang disebabkan oleh berkurangnya daya dukung tanah akibat adanya excavation atau penggalian di dalam massa batuan. Salah satu hal yang harus diperhatikan dalam penambangan bawah tanah adalah faktor keamanan lubang tambang. Faktor keamanan lubang tambang tidak hanya dipengaruhi oleh kekuatan batuan namun juga keadaan batuan penyusunnya seperti adanya struktur geologi.

Analisa mengenai kuat tekan batuan penyusun lubang tambang bawah tanah di PT. NAL Sawahlunto sangat diperlukan untuk mengetahui berapa lama lubang tambang di PT. NAL Sawahlunto dapat bertahan menyangga tekanan batuan penyusunnya sendiri, sehingga terjadinya subsidence sebelum waktunya dapat diantisipasi.

Tujuan dari penelitian ini adalah:

1. Menghitung berapa kuat tekan batuan penyusun lubang tambang bawah tanah C1-G PT. NAL Sawahlunto.

2. Menganalisa stand-up time lubang tambang bawah tanah C1-G PT. NAL Sawahlunto.

\section{METODOLOGI}

\section{Jenis Penelitian}

Jenis penelitian yang penulis lakukan adalah penelitian terapan (applied research). Menurut Moh. Nazir (2017, hal. 17). Penelitian terapan adalah penyelidikan yang hati-hati, sistematik dan terus-menerus terhadap suatu masalah dengan tujuan untuk digunakan dengan segera untuk keperluan tertentu. Hasil penelitian tidak perlu sebagai penemuan baru, tetapi merupakan aplikasi baru dari penelitian yang telah ada.

Pengambilan data pada penelitian ini dilakukan dengan dua metode, yaitu observasi di lapangan dan pengujian di laboratorium. Adapun data yang diperoleh dari observasi dilapangan berupa data jarak kekar, kondisi kekar dan kondisi air tanah yang didapatkan dengan membentangkan scanline sepanjang $20 \mathrm{~m}$. serta orientasi diskontinuitas/kekar yang diukur menggunakan kompas geologi. Sedangkan data yang diperoleh dari pengujian laboratorium berupa data Unconfined Compressive Strength (UCS) yang didapatkan melalui pengujian Point Load Index (PLI) dan data sifat fisik batuan.

\section{Lokasi Penelitian}

Penelitian ini secara administratif dilakukan di perusahaan tambang batubara bawah tanah PT. NAL Desa Salak, Kecamatan Talawi Kota Sawahlunto, Provinsi Sumatera Barat, wilayah tersebut terletak di sebelah timur laut Kota Padang dan secara geografis terletak pada $00^{\circ} 36^{\prime}$ $45,84^{\prime}$ ' $-00^{\circ} 37^{\prime} 12,10$ ' $\mathrm{LS}$ dan $100^{\circ} 45^{\prime}$ 48,19''BT-100 46' 48,20' 'BT.

\section{HASIL DAN PEMBAHASAN Rock Mass Rating System (RMR)}

Dari hasil uji kuat tekan yang telah dilakukan, didapatkan nilai rata-rata kuat tekan 4.620 Mpa untuk batubara yang dikategorikan sebagai batuan sangat lemah (very weak), untuk batupasir dan batulanau dikategorikan lemah (weak) dengan nilai kuat tekan 8.835 Mpa dan Mpa. Menurut jurnal teknologi pertambangan volume 1 Nomor 1 Faisal Akbar dkk 2015 batuan yang termasuk dalam kondisi sangat jelek (very weak) dengan kuat tekan $<5 \mathrm{Mpa}$ dapat mengakibatkan terjadinya potensi resiko keruntuhan atap pada area penambangan yang lebih besar. 


\section{Nilai RQD}

Nilai yang diperlukan selanjutnya adalah nilai RQD yang telah diolah sebelumnya, sehingga didapatkanlah hasil seperti ditunjukkan pada tabel 1 di bawah ini:

Tabel 1. Nilai RQD

\begin{tabular}{|c|l|c|c|}
\hline No & \multicolumn{1}{|c|}{ Batuan } & Jarak Kekar & Bobot \\
\hline 1 & Batupasir (scanline I) & $119 \mathrm{~cm}$ & \multirow{2}{*}{15} \\
\cline { 1 - 3 } 2 & Batulanau (scanline II) & $198,9 \mathrm{~cm}$ & \\
\hline 3 & Batupasir (scanline III) & $70,38 \mathrm{~cm}$ & \\
\hline
\end{tabular}

Tabel 2. Jarak Kekar

\begin{tabular}{|c|c|c|c|}
\hline Deskripsi & $\begin{array}{c}\text { Spasi } \\
\text { kekar }(m)\end{array}$ & Bobot & $\begin{array}{c}\text { Jarak } \\
\text { Antar } \\
\text { Spasi }\end{array}$ \\
\hline Sangat lebar (very wide) & $>2$ & 20 & \multirow{5}{*}{$\begin{array}{c}1.19 \\
\mathrm{~m} \\
1.19 \mathrm{~m}\end{array}$} \\
\hline Lebar (wide) & $0,6-2$ & 15 & \\
\hline Sedang (moderate) & $0,2-0,6$ & 10 & \\
\hline Rapat (close) & $0,006-0,2$ & 8 & \\
\hline Sangat rapat (very close) & $<0,006$ & 5 & \\
\hline
\end{tabular}

Sumber: Made Astawa Rai dkk (2011, hal. 433)

\section{Kondisi Discontinue/kekar}

Kemenerusan (persistence) yang merupakan panjang dari kekar, berdasarkan hasil dari perhitungan yang dilakukan didapatkan nilai panjang rata- rata kekar kurang dari 1 (satu) meter dengan bobot 6 yang merupakan bobot tertinggi dari tabel pembobotan panjang kekar. Semakin pendek kemenerusan dari kekar, maka semakin baik kualitas dari massa batuan yang diukur.

Bukaan kekar diartikan sebagai lebar kekar yang ada. Dari pengukuran dan perhitungan data yang ada, didapatkan nilai bukaan kekar berada pada rentang 1-5 mm untuk batupasir dan batulanau serta 0.1-1.0 mm untuk batubara, Semakin besar bukaan kekar, maka semakin buruk kualitas massa batuan yang ada.

Kekasaran berfungsi sebagai pengunci permukaan bidang kekar, yang mana semakin kasar bidang batuan maka semakin kecil kekuatan geser bidang pada massa batuan, sehingga pergerakan bidang batuan akan berkurang.

Isian (infilling) yang merupakan isian celah antar permukaan bidang kekar, material pengisi akan mempengaruhi kuat geser bidang kekar, yang mana tergantung ketebalannya, isian menghambat penguncian yang diakibatkan kekerasan rekahan. Dari penelitian yang dilakukan, tidak ada isian diseluruh kekar yang telah diukur dan setelah dicocokkan dengan tabel pembobotan memiliki bobot 6. Dari tabel tersebut dapat diketahui bahwa massa batuan dengan kekar tanpa isian memiliki nilai yang baik.

Selain isian, hal lain yang mempengaruhi kuat geser bidang batuan adalah kelapukan, yang mana semakin lapuk suatu bidang kekar, maka semakin besar kuat geser pada bidang batuan. Berdasarkan data dilapangan, kondisi bidang pada kekar terlihat sangat lapuk, lapuk dan tidak lapuk. Pada saat dicocokkan dengan tabel pembobotan, didapatkanlah bobot untuk pelapukan sebesar 1 .

\section{Kondisi Air Tanah}

Kondisi air tanah pada terowongan perhitungan besaran masuknya air tanah dihitung dalam satuan liter per $10 \mathrm{~m}$ dari penggalian. Sebagai alternatif, kondisi umum dapat dinyatakan dalam kering, lembab, basah, menetes dan mengalir (Made Astawa Rai dkk 2011, hal. 409 dan Z. T Bieniawski 1989, hal. 23 serta Jurnal eksplorium vol 37 no 2 Dhatu kamajati dkk 2016). Berdasarkan penelitian di lapangan, kondisi air tanah relatif kering, yang mana untuk predikat air tanah kering mempunyai bobot 15 yang merupakan bobot tertinggi dari pembobotan kondisi air tanah. Dari pembobotan tersebut, dapat diketahui bahwa semakin rendah kandungan air tanah, maka semakin baik kualitas massa batuan.

Dari kondisi air tanah masing- masing kekar yang ada, dapat disimpulkan bahwa rata-rata kekar memiliki kondisi air tanah yang kering, sehingga apabila ditentukan bobotnya pada tabel pembobotan, akan didapatkan bobot sebesar 15 . 


\section{Orientasi Diskontinuitas}

Posisi strike dan dip akan menentukan apakah penggalian akan menguntungkan, tidak menguntungkan atau sedang. Dari hasil pengolahan data dan analisa terhadap strike dan dip didapatkan strike bidang kekar sejajar/paralel dengan sumbu terowongan dengan arah dip searah penggalian sebesar (berdasarkan kaidah tangan kiri). Maka diperoleh pengaruh orientasi kekar terhadap penerowongan dengan bobot tertentu.

Dari data orientasi kekar yang telah didapatkan berupa data strike dan dip, kemudian dianalisa menggunakan diagram Rosette pada software Dips 5.0 dan didapatkanlah hasil orientasi kekar seperti pada gambar 1, 2 dan 3. Terdapat beberapa aturan yang dikemukakan dalam buku Mekanika Batuan, Made Astawa Rai dkk (2011, hal 434), ada 2 (dua) kondisi orientasi kekar yaitu tegak lurus sumbu terowongan dan sejajar sumbu terowongan. Semakin kekar sejajar dengan sumbu terowongan, maka semakin tidak menguntungkan untuk keamanan terowongan tersebut.

\section{Batupasir}

Berikut adalah hasil plot orientasi kekar pada batupasir menggunakan diagram rossete:

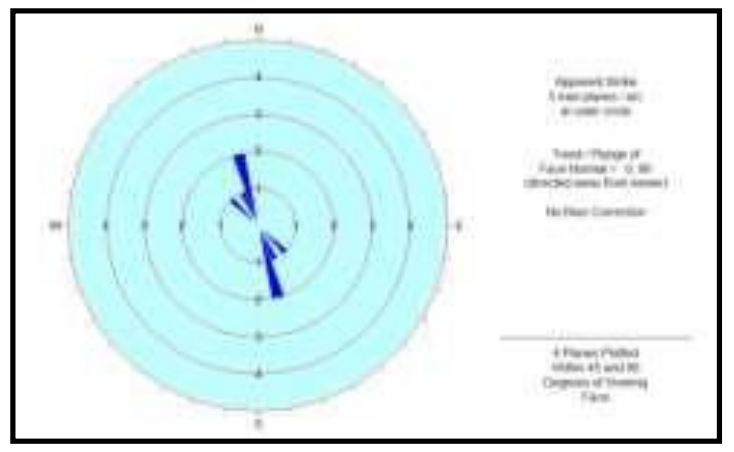

Gambar 1.

Hasil Diagram Rosette Orientasi Kekar Batupasir

Dari diagram rosette di atas, dapat dikatakan bahwa orientasi kekar tegak lurus terhadap terowongan, yang mana strike dominan berada pada rentang 340-350 dan dip dominan berada pada rentang 70-80. Berdasarkan tabel 5 dan tabel 6, untuk orientasi kekar yang tegak lurus sumbu terowongan berada pada rentang $45^{\circ}-90^{\circ}$ dan memiliki nilai peubah "sedang" dengan bobot penilaian -5 (min lima).

Hubungan antara RMRbasic dengan Orientasi kekar ditunjukkan pada tabel 4.

Tabel 3. Pengaruh Orientasi Kekar dalam Pembuatan Terowongan dan Penggalian (Fowell \& Johnson, 1991)

\begin{tabular}{|c|c|c|c|c|c|c|}
\hline \multicolumn{4}{|c|}{ Pengaruh jurus \& kemiringan kekar untuk penerowongan } \\
\hline \multicolumn{3}{|c|}{$\begin{array}{c}\text { Jurus tegak lurus sumbu } \\
\text { terowongan }\end{array}$} & \multicolumn{2}{c|}{$\begin{array}{c}\text { Jurus paralel } \\
\text { sumbu } \\
\text { terowongan } \\
\text { ngan }\end{array}$} & $\begin{array}{c}\text { Tidak } \\
\text { tergantun } \\
\text { g jurus }\end{array}$ \\
\hline Daip & Dip & Dip & Dip & Dip & Dip & Dip \\
\hline $45^{\circ}-90^{\circ}$ & $\begin{array}{c}20^{\circ}- \\
45^{\circ}\end{array}$ & $\begin{array}{c}45^{\circ}- \\
90^{\circ}\end{array}$ & $\begin{array}{c}20^{\circ}- \\
45^{\circ}\end{array}$ & $\begin{array}{c}45^{\circ}- \\
90^{\circ}\end{array}$ & $\begin{array}{c}20^{\circ}- \\
45^{\circ}\end{array}$ & $0^{\circ}-20^{\circ}$ \\
\hline $\begin{array}{c}\text { Sangat } \\
\text { mengu } \\
\text { ntungk } \\
\text { an }\end{array}$ & $\begin{array}{c}\text { mengu } \\
\text { ntungk } \\
\text { an }\end{array}$ & $\begin{array}{c}\text { sedan } \\
\text { g }\end{array}$ & $\begin{array}{c}\text { Tidak } \\
\text { mengu } \\
\text { ntungk } \\
\text { an }\end{array}$ & $\begin{array}{c}\text { at } \\
\text { tidak } \\
\text { meng } \\
\text { untun } \\
\text { gkan }\end{array}$ & $\begin{array}{c}\text { seda } \\
\text { ng }\end{array}$ & $\begin{array}{c}\text { Tidak } \\
\text { mengunt } \\
\text { ungkan }\end{array}$ \\
\hline
\end{tabular}

Tabel 4. RMR-B Peubah Bobot Orientasi Kekar (Bieniawski, 1989; Fowell \& Johnson, 1991)

\begin{tabular}{|c|c|c|c|c|c|c|}
\hline \multicolumn{2}{|c|}{$\begin{array}{c}\text { Jurus \& } \\
\text { Kemiringan } \\
\text { Orientasi Kekar }\end{array}$} & $\begin{array}{c}\text { Sangat } \\
\text { Meng } \\
\text { untung } \\
\text { kan }\end{array}$ & $\begin{array}{c}\text { Me } \\
\text { ngu } \\
\text { ntun } \\
\text { gka } \\
\text { n }\end{array}$ & $\begin{array}{c}\text { Seda } \\
\text { ng }\end{array}$ & $\begin{array}{c}\text { Tidak } \\
\text { Mengu } \\
\text { ntungka } \\
\text { n }\end{array}$ & $\begin{array}{c}\text { Sangat } \\
\text { Tidak } \\
\text { Menguntu } \\
\text { ngkan }\end{array}$ \\
\hline \multirow{2}{*}{$\begin{array}{c}\text { Bob } \\
\text { ot }\end{array}$} & $\begin{array}{c}\text { Terowo } \\
\text { ngan }\end{array}$ & 0 & -2 & -5 & -10 & -12 \\
\cline { 2 - 7 } & Fondasi & 0 & -2 & -7 & -15 & -25 \\
\cline { 2 - 7 } & Lereng & 0 & -2 & -25 & -50 & -60 \\
\hline
\end{tabular}

Tabel 5. Bobot RMR Keseluruhan Batupasir

\begin{tabular}{|c|l|c|c|c|c|c|}
\hline No & Parameter & Bobot & $\begin{array}{c}\text { Hasil } \\
\text { Bobot }\end{array}$ & Rating & $\begin{array}{c}\text { No } \\
\text { Class }\end{array}$ & $\begin{array}{c}\text { Descr } \\
\text { ption }\end{array}$ \\
\hline 1 & UCS & 1 & & & & \\
\hline 2 & RQD & 20 & & & & \\
\hline 3 & $\begin{array}{l}\text { Jarak Antar } \\
\text { Kekar }\end{array}$ & 15 & \multirow{2}{*}{62} & $80-60$ & II & $\begin{array}{c}\text { Goodr } \\
\text { ock }\end{array}$ \\
\cline { 1 - 2 } 4 & Kondisi Kekar & 18 & & & & \\
\hline 5 & $\begin{array}{l}\text { Kondisi Air } \\
\text { Tanah }\end{array}$ & 15 & & & & \\
\hline 6 & Orientasi Kekar & -5 & & & & \\
\hline
\end{tabular}


Berdasarkan tabel 5 dengan nilai RMR 64 maka massa batupasir berada pada rating 61-80 dengan deskripsi Good Rock dan berada pada kelas batuan no II.

\section{Batu lanau}

Untuk hasil pengolahan data dari orientasi kekar pada scanline batulanau, dapat dilihat pada gambar 2 .

Hubungan antara RMRbasic dengan Orientasi kekar ditunjukkan pada tabel 6.

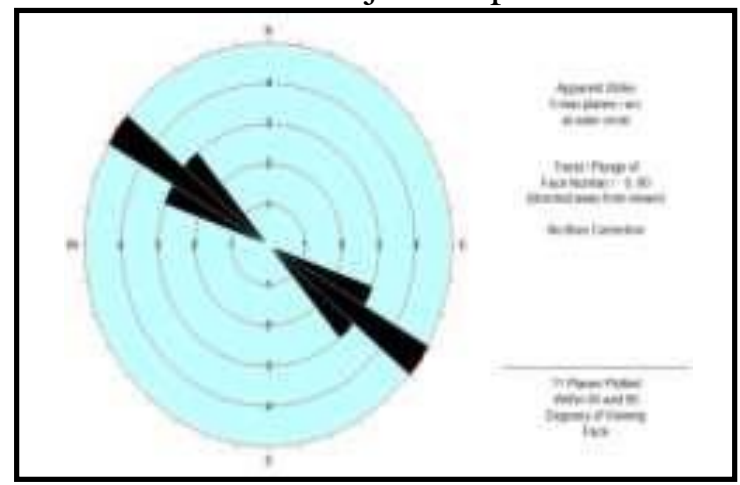

Gambar 2

Hasil Diagram Rosette Orientasi Kekar Batulanau

Tabel 6. Bobot Keseluruhan Batulanau dari RMR

\begin{tabular}{|c|c|c|c|c|c|c|}
\hline No & Parameter & Bobot & $\begin{array}{l}\text { Hasil } \\
\text { Bobot }\end{array}$ & Rating & $\begin{array}{c}\text { No } \\
\text { Class }\end{array}$ & $\begin{array}{c}\text { Desc } \\
\text { ripti } \\
\text { on }\end{array}$ \\
\hline 1 & UCS & 2 & \multirow{6}{*}{62} & \multirow{6}{*}{$\begin{array}{c}80 \\
- \\
60\end{array}$} & \multirow{6}{*}{ II } & \multirow{6}{*}{$\begin{array}{l}\text { Good } \\
\text { rock }\end{array}$} \\
\hline 2 & RQD & 20 & & & & \\
\hline 3 & $\begin{array}{l}\text { Jarak } \\
\text { Antar } \\
\text { Kekear }\end{array}$ & 15 & & & & \\
\hline 4 & $\begin{array}{l}\text { Kondisi } \\
\text { Kekar }\end{array}$ & 22 & & & & \\
\hline 5 & $\begin{array}{l}\text { Kondisi } \\
\text { Air } \\
\text { Tanag }\end{array}$ & 15 & & & & \\
\hline 6 & $\begin{array}{l}\text { Orientas } \\
\text { i Kekar }\end{array}$ & -10 & & & & \\
\hline
\end{tabular}

Pada diagram rosette di atas, dapat dikatakan bahwa orientasi kekar batulanau 'tidak menguntungkan' dengan strike dominan berada pada $300^{\circ}-310^{\circ}$ dan dip dominan berada antara $30^{\circ}-40^{\circ}$, apabila dilihat pada tabel 8 orientasi kekar tegak lurus sumbu terowongan dan berada pada rentang $20^{\circ}-35^{\circ}$ dengan nilai peubah 'tidak menguntungkan' berbobot -10 (min sepuluh).

\section{Batubara}

Berikut adalah hasil diagram orientasi batu bara (gambar 3).

Dapat dilihat pada gambar bahwa jurus utama pada diagram rosette berada antara $280^{\circ}-290^{\circ}$ sedangkan arah dip utama terletak antara $10^{\circ}-20^{\circ}$. Berdasarkan tabel 5 posisi stike parallel sumbu terowongan, sehingga didapatkanlah nilai 'sedang' dengan bobot berdasarkan tabel 6 sebesar -5 (min lima).

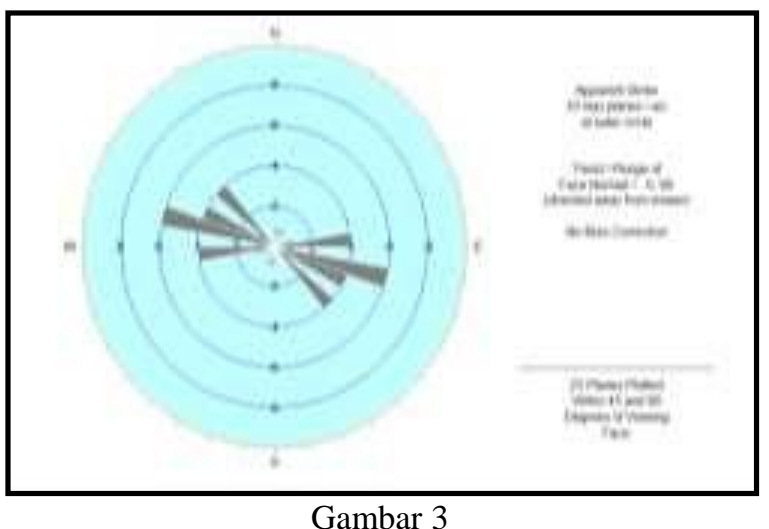

Hasil Diagram Rosette Orientasi Kekar Batubara

Hubungan antara RMRbasic dengan orientasi kekar ditunjukkan pada tabel 7. Dengan nilai bobot RMR 67, dapat diklasifikasikan kelas massa batuan berada pada kelas II dengan deskripsi 'Good rock'.

Tabel 7. Bobot Keseluruhan Batubara dari RMR

\begin{tabular}{|c|c|c|c|c|c|c|}
\hline No & Parameter & Bobot & $\begin{array}{l}\text { Hasil } \\
\text { Bobot }\end{array}$ & Rating & $\begin{array}{c}\text { No } \\
\text { Class } \\
\end{array}$ & $\begin{array}{c}\text { Descriptio } \\
n\end{array}$ \\
\hline 1 & UCS & 2 & \multirow{6}{*}{67} & \multirow{6}{*}{$\begin{array}{c}80- \\
60\end{array}$} & \multirow{6}{*}{ II } & \multirow{6}{*}{$\begin{array}{c}\text { Good } \\
\text { rock }\end{array}$} \\
\hline 2 & RQD & 17 & & & & \\
\hline 3 & $\begin{array}{l}\text { Jarak Antar } \\
\text { Kekear }\end{array}$ & 15 & & & & \\
\hline 4 & $\begin{array}{l}\text { Kondisi } \\
\text { Kekar }\end{array}$ & 23 & & & & \\
\hline 5 & $\begin{array}{l}\text { Kondisi Air } \\
\text { Tanag }\end{array}$ & 15 & & & & \\
\hline 6 & $\begin{array}{l}\text { Orientasi } \\
\text { Kekar }\end{array}$ & -5 & & & & \\
\hline
\end{tabular}

\section{Stand-up Time}

Stand-up Time didapatkan dengan memasukkan nilai RMR ke dalam grafik stand-up time (gambar 4). 


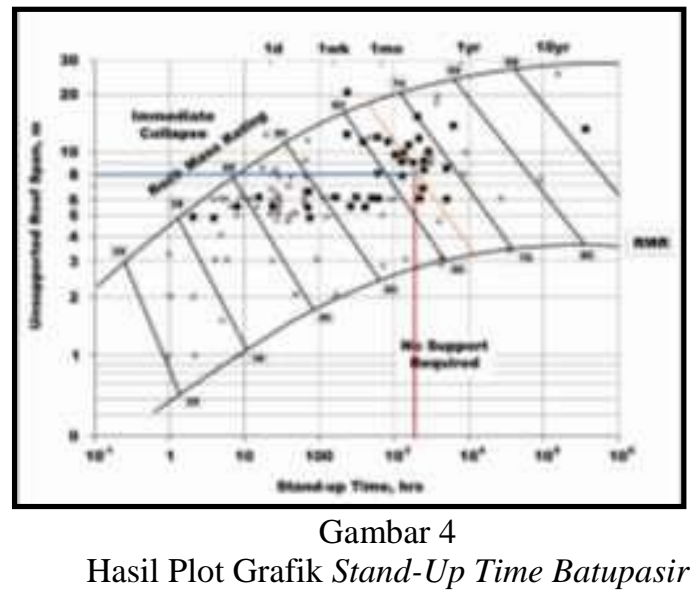

Batupasir memiliki nilai RMR 64, setelah dilakukan plot pada grafik stand-up time, didapatkan nilai sebesar \pm 500 jam atau sekitar 3 bulan 12 hari dengan span 8 $\mathrm{m}$.

Batulanau memiliki nilai RMR 62, setelah dilakukan plot pada grafik stand- up time, didapatkan nilai sebesar \pm 2000 jam atau sekitar 2 bulan 21 hari dengan span 7.5 m.

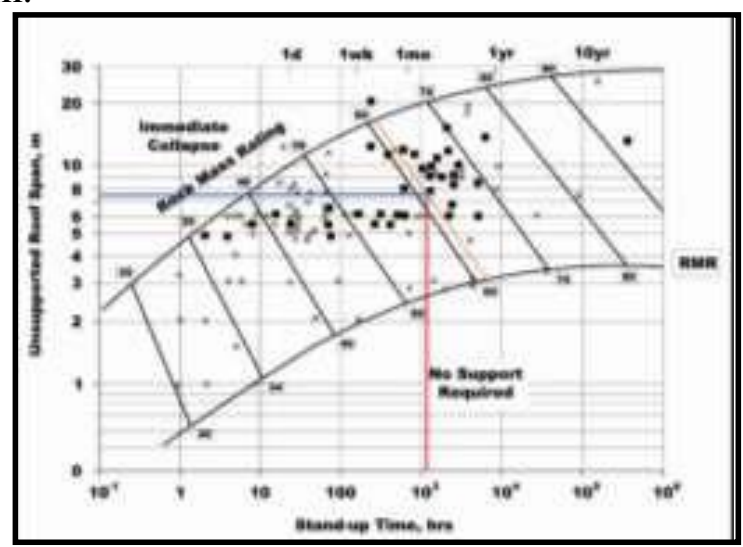

Gambar 5

Hasil Plot Grafik Stand-Up Time Batulanau

Batubara memiliki nilai RMR 67 setelah dilakukan plot pada grafik stand up time, didapatkan nilai sebesar \pm 5000 jam atau sekitar 6 bulan 27 hari dengan span 8 $\mathrm{m}$.

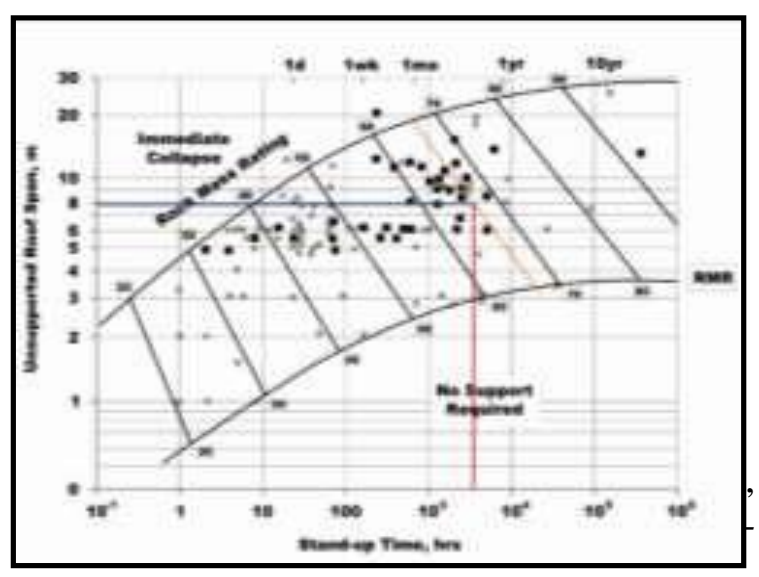

Gambar 6

Hasil Plot Grafik Stand-Up Time Batubara

Sebagai bahan pertimbangan dalam perencanaan pembukaan lubang penambangan maupun kemajuan penggalian PT. NAL, dapat disarankan pemakaian nilai RMR terendah sebagai antisipasi keadaan terburuk yang mungkin terjadi. Akan tetapi, nilai RMR yang didapat sangat dipengaruhi oleh orientasi kekar yang terbentuk. Untuk petunjuk penggalian dan penyanggaan berdasarkan nilai RMR dapat diliat pada tabel 3.11, yaitu dengan kemajuan full face 1-1.5 $\mathrm{m}$ dan support $20 \mathrm{~m}$ from face.

\section{Sifat Fisik Batuan}

Berikut adalah hasil uji sifat fisik batuan

Semakin tinggi kadar air, menunjukkan bahwa nilai angka pori pada batuan semakin tinggi, semakin tinggi pula kadar air menunjukkan bahwa tingkat kejenuhan air pada massa batuan semakin tinggi. Jika nilai derajat kejenuhan semakin tinggi, maka kuat geser batuan semakin rendah begitu juga sebaliknya. 
Tabel 8. Hasil Sifat Fisik Batuan

\begin{tabular}{|l|c|c|c|c|c|}
\hline Sampel & $\begin{array}{c}\text { Berat } \\
\text { Jenis } \\
\text { Sejati }\end{array}$ & $\begin{array}{c}\text { Kadar Air Kandungan } \\
\text { Asli) }\end{array}$ & $\begin{array}{c}\text { Derajat } \\
\text { Air Jenuh } \\
(\%)\end{array}$ & $\begin{array}{c}\text { Pojenuhan, } \\
\text { Kejos, } \\
\text { n \% }\end{array}$ & \\
\hline $\begin{array}{l}\text { Batu } \\
\text { lanau }\end{array}$ & 2.649 & 0.007 & 0.044 & 0.166 & 0.177 \\
\hline $\begin{array}{l}\text { Batu } \\
\text { pasir }\end{array}$ & 2.670 & 0.023 & 0.080 & 0.293 & 0.214 \\
\hline $\begin{array}{l}\text { Batu } \\
\text { bara }\end{array}$ & 1.191 & 0.040 & 0.052 & 0.778 & 0.061 \\
\hline
\end{tabular}

\section{KESIMPULAN}

Berdasarkan hasil dan pembahasan dari pengolahan data yang didapatkan dari lokasi penambangan $\mathrm{C} 1-\mathrm{G}$ PT. NAL, dapat disimpulkan bahwa:

1. Nilai kuat tekan batuan penyusun lubang tambang C1-G 4.620 Mpa untuk batubara (sangat lemah), 8.835 Mpa untuk batupasir (lemah) dan 13.367 Mpa untuk batulanau (lemah). Nilai kuat tekan batuan yang tergolong lemah akan menyebabkan terjadinya potensi resiko keruntuhan atap lokasi penambangan yang lebih besar.

2. Berdasarkan analisa menggunakan grafik stand-up time, batupasir memiliki nilai RMR 64 dengan stand-up time sebesar \pm 2500 jam atau sekitar 3 bulan 12 hari, span $8 \mathrm{~m}$. Batulanau memiliki nilai RMR 62, stand-up time sebesar \pm 2000 jam atau sekitar 2 bulan 21 hari dengan span $7.5 \mathrm{~m}$. Batubara memiliki nilai RMR 67, stand-up time sebesar \pm 5000 jam atau sekitar 6 bulan 27 hari dengan span $8 \mathrm{~m}$. Dengan asumsi penggunaan nilai RMR terendah yaitu 62 untuk mengantisipasi keadaan terburuk dari batuan penyususn lubang tambang bawah tanah C1-G PT. NAL. Untuk petunjuk penggalian dan penyanggaan berdasarkan nilai RMR menurut Bieniawski (1973) yaitu dengan kemajuan full face 1-1.5 m dan support $20 \mathrm{~m}$ from face.

\section{SARAN}

1. Sebaiknya tidak melakukan penggalian terlalu dalam pada setiap kemajuan lubang penambangan dengan kondisi batuan yang lemah, karena akan menyebabkan terjadinya peningkatan tekanan yang dapat menyebabkan meningkatnya resiko keruntuhan atap lokasi penambangan.

2. Penelitian lanjutan pada lubang tambang PT. NAL sangat dianjurkan karena masih banyak kekurangan- kekurangan dalam pengambilan dan pengolahan data yang disebabkan oleh kurangnya kemampuan peneliti dan kondisi lapangan.

\section{DAFTAR PUSTAKA}

Beemer, H.D, Worrells D.S. 2017. Conducting Rock Mass Rating for tunnel construction on Mars. Astronautica, Juli 2017: 176-180.

Bieniawski, Z.T, Engineering Rockmass Classification: A Complete Manual For Engineers And Geologist In Mining, Civil And Petroleum Engineering, A Wiley-Interscience Publication, Canada, 1989.

Ellisa Tirayoh dan Arista Muhartanto, 2014. Analisis Struktur Geologi Dan Penambangan Bawah Tanah Terhadap Propagasi Subsidence Di Daerah Ertsberg Pt Freeport Indonesia, Papua. Mindagi, Juli 2014: 13-22.

Faisal Akbar Tri Erto Putra, Singgih Saptono, Peter Eka Rosadi. 2015. Kajian Geoteknik Terhadap Rancangan Penambangan Batubara Bawah Tanah Metode Shortwall Di Cv. Artha Pratama Jaya, Kecamatan Muara Jawa,Kabupaten Kutai Kartanegara, Provinsi Kalimantan Timur. Teknologi Pertambangan, Maret-Agustus 2015: 37-45.

Galvan, G, Preciado, J, Seron, J. 2014. Correlation Between The Point Load Index, Is(50), And The Resistance To Unconfined Compression In Limestone From The Comunidad Valenciana, 
Spain. Geotechnica, Februari 2014: 25-35.

Heri Syaeful, Dhatu Kamajati. 2015. Analisis Karakteristik Massa Batuan di Sektor Lemajung, Kalan, Kalimantan Barat. Eksplorium, Mei 2015: 17-30.

Irwandy Arif, Batubara Indonesia, PT. Gramedia Pustaka Utama, Jakarta, 2014.

Laubscher, D.H, 1990. A Geomechanics Classification System For The Rating Of Rock Mass In Mine Design. Mining And Metallurgy, Oktober 1990: $257-$ 273.

Made Astawa Rai, Suseno ramadibrata, Ridho Kresna Wattimena, Mekanika Batuan, Laboratorium Geomekanika dan Peralatan Tambang, Institute Teknologi Bandung, Bandung, 2011.

Moh. Nazir, Metode Penenlitian. Ghalia Indonesia, Bogor, 2017.

Muhammad Dahlan B, Geologi Untuk Pertambangan Umum, Graha Ilmu, Yogyakarta, 2015.

Ocsen Gregorius Talinusa, Ruddy Tenda, Winny J. Tamboto. 2014. Pengaruh Dimensi Benda Uji Terhadap Kuat Tekan Beton. Sipil, November 2014: 334-351.

Sukandarrumidi., Batubara dan Pemanfaatannya, Gadjah Mada University Press, Yogyakarta, 2005.

Yoszi Mingsi Anaperta, 2013. Studi Terowongan Jalan Raya PadangSolok. 